\title{
Rahab the harlot in Severian of Gabala's De paenitentia et compunctione (de Rahab historia): Paradox, anti-Judaism and the early Christian invention of the penitent prostitute
}

\begin{tabular}{|c|c|}
\hline \multicolumn{2}{|c|}{$\begin{array}{l}\text { Author: } \\
\text { Chris L. de Wet }{ }^{1,2}\end{array}$} \\
\hline \multicolumn{2}{|c|}{$\begin{array}{l}\text { Affiliations: } \\
{ }^{1} \text { Department of Biblical and } \\
\text { Ancient Studies, University } \\
\text { of South Africa, Pretoria, } \\
\text { South Africa }\end{array}$} \\
\hline \multicolumn{2}{|c|}{$\begin{array}{l}{ }^{2} \text { Faculty of Australian } \\
\text { Lutheran College, University } \\
\text { of Divinity, Adelaide, } \\
\text { Australia }\end{array}$} \\
\hline \multicolumn{2}{|c|}{$\begin{array}{l}\text { Corresponding author: } \\
\text { Chris de Wet, } \\
\text { chrisldw@gmail.com }\end{array}$} \\
\hline \multicolumn{2}{|c|}{$\begin{array}{l}\text { Dates: } \\
\text { Received: } 17 \text { Aug. } 2020 \\
\text { Accepted: } 09 \text { Sept. } 2020 \\
\text { Published: } 16 \text { Nov. } 2020\end{array}$} \\
\hline \multicolumn{2}{|c|}{$\begin{array}{l}\text { How to cite this article: } \\
\text { De Wet, C.L., 2020, 'Rahab } \\
\text { the harlot in Severian of } \\
\text { Gabala's De paenitentia et } \\
\text { compunctione (de Rahab } \\
\text { historia): Paradox, anti- } \\
\text { Judaism and the early } \\
\text { Christian invention of the } \\
\text { penitent prostitute', HTS } \\
\text { Teologiese Studies/ } \\
\text { Theological Studies } 76(3) \text {, } \\
\text { a6309. https://doi.org/ } \\
\text { 10.4102/hts.v76i3.6309 }\end{array}$} \\
\hline \multicolumn{2}{|c|}{$\begin{array}{l}\text { Copyright: } \\
\text { (C) 2020. The Authors } \\
\text { Licensee: AOSIS. This } \\
\text { is licensed under the } \\
\text { Creative Commons } \\
\text { Attribution License. }\end{array}$} \\
\hline \multicolumn{2}{|l|}{ Read online: } \\
\hline artip & $\begin{array}{l}\text { Scan this QR } \\
\text { code with your } \\
\text { smart phone or } \\
\text { mobile device } \\
\text { to read online. }\end{array}$ \\
\hline
\end{tabular}

This article examines the 4th-century CE interpretation of the story of Rahab the Harlot by Severian of Gabala, in his homily, De paenitentia et compunctione (CPG 4186). In this article, a close and critical reading of Severian's references to the story of Rahab in De paenitentia et compunctione (with some comparative reference to other works of Severian, and also of John Chrysostom and Pseudo-Chrysostom) is provided. It is asked, 'how and why could a treacherous harlot, a prostitute, who was considered to be the epitome of vice in early Christian moral deliberations, function as an exemplum for Severian?' The article firstly asks how Severian deals with the problematic and paradoxical aspects of Rahab, namely, the fact that she was a prostitute and also a liar. Then, it illustrates how Severian transforms Rahab into a Christian heroine and how he deploys these qualities of the transformed Rahab in a potent anti-Judaistic rhetoric. This study is finally concluded with a somewhat broader delineation of the importance of Rahab in the development of a curious Christian cultural and moral trope, namely, the penitent prostitute. Such a study of Rahab is significant not only in that it expands our understanding of the history of women and gender dynamics in early Christianity, but it also elucidates the complex and strategic discursive moves employed by male Christian authors to deal with the seemingly 'bad girls' of scripture.

Contribution: This article investigates the historical reception of the story of Rahab (Jos 2) in a little-known homily by Severian of Gabala. The focus is how Severian interprets the story and the paradoxical figure that is Rahab, with reference to its use as an anti-Judaistic trope, and its role in the shaping of the cultural phenomenon that is the penitent prostitute in early Christian thought.

Keywords: Severian of Gabala; Rahab; early Christian biblical interpretation; anti-Judaism; Book of Joshua; John Chrysostom; Pseudo-John Chrysostom; penitent prostitute.

\section{Introduction}

The tale of Rahab is, by all accounts, one of the most fascinating, even suspenseful, stories of the Hebrew Bible. In the second chapter of the Book of Joshua, we read that Israelite spies were sent by Joshua to Jericho as scouts. They entered the house of a woman known as Rahab, who was considered to be a prostitute (זָנז, as per Jos 2:1), where they spent the night. When the city authorities came searching for the spies, Rahab hid the spies and told the guards that they had already left the city, sending the guards on a wild goose chase, so to speak. In exchange for this act of protection, Rahab only asks that she and her family be spared when the Israelites invade the city. She indeed confesses:

I know that the Lord has given you the land, and that dread of you has fallen on us, and that all the inhabitants of the land melt in fear before you. For we have heard how the Lord dried up the water of the Red Sea before you when you came out of Egypt, and what you did to the two kings of the Amorites that were beyond the Jordan, to Sihon and Og, whom you utterly destroyed. As soon as we heard it, our hearts melted, and there was no courage left in any of us because of you. The Lord your God is indeed God in heaven above and on earth below. (Jos 2:9-11 NRSV)

Not only does she seem to recognise the military superiority of Israel, but more so she states that the God of Israel is the true God. This act of Rahab enables the Israelites to successfully conquer the city of Jericho, arguably one of the most famous and memorable Israelite victories in the Hebrew Bible. In Joshua 6:17, 22-25, Rahab and her family are spared and brought into Israel.

In its historical and literary reception, the story of Rahab was interpreted in various ways, both by Rabbis and early Christian authors. The character of Rahab, even in her ancient Hebrew Bible 
context, is paradoxical (Raveh 2014:102-104). She exhibits a tension between what Raveh (2014:102) calls the typical 'bad girl' stereotype; yet, she also saves the 'good guys' and makes the victory at Jericho possible. This paradox was maintained in the reception of the story in late antiquity. Raveh (2014) further notes:

Their [the Israelites'] passing 'via' the harlot who is destined to convert becomes, in rabbinic literature, a symbol of their domination of the space of the 'heterotopic' other, taming it and civilizing it. (p. 113)

Indeed, Rahab becomes the example of the 'ideal proselyte' in rabbinic literature, and the prophetess Huldah (in $2 \mathrm{Kg}$ 22:14-20 and 2 Chr 34:22-28) is actually listed as one of Rahab's descendants (Baskin 1979:141-157).

Rahab was also popular - and equally paradoxical! - in the early Christian imagination. In the New Testament, she is $\left(\right.$ possibly $^{1}$ ) listed in the genealogy of Christ in Matthew 1:5. In Hebrews 11:31, it is stated that Rahab did not perish because of her faith, while James 2:25 explains that Rahab was justified by her good works (see Hanson 1978:53-60; Japinga 2017:66-70). In the Latin Christian tradition, Ambrose of Milan (c. 340-397 CE) uses the oxymoron casta meretrix ('a chaste harlot') to describe Rahab (see Ambrose, In Lucam 3; cited in Kritzinger 2006:23). Other Latin Christian authors hail Rahab's hospitality, her foresight, her faith and her good works (Kritzinger 2006:24-28). Similar formulations are found in the Greek patristic tradition, as Stander (2006:37-49) has shown. In the Syriac tradition, Ephrem emphasised Rahab's boldness and paradoxicality as a female biblical figure (Botha 2006:1-21).

The tale of Rahab, both in her original Hebrew Bible context and in the literary reception of her story, has received much scholarly attention. Perhaps, one of the most important reasons for this is that the figure of Rahab does exceptionally well to problematise issues of gender, ethnicity and power in antiquity, as Raveh (2014:100-115) has especially demonstrated (see also Japinga 2017:66-70). As noted above, Rahab's reception in early Christianity received special attention in 2006 in a special section in the journal Acta Patristica et Byzantina. In this section, Kritzinger examined Rahab in the Latin tradition, Botha in the Syriac (notably, Ephrem) and Stander in the Greek tradition. A broader overview of the reception of Rahab is also given by Lyons (2008:n.p.).

This study aims to examine one author's reading of Rahab in the Greek Christian tradition, namely, that of Severian of Gabala (d. ca. 408 CE). Details about Severian's life and works are limited, although he has received more attention in recent times (see especially Voicu 2014:563-564, 2019:259-283). Severian is often discussed in relation to John Chrysostom (ca. 347-407 CE). After some time of possible friendship, it see Quin (1981:225-228) and Bauckham (1995:313-329). seems as if some animosity bred between Severian and Chrysostom, and Severian was involved, in some way, with the deposition of Chrysostom (Van Nuffelen 2019:245-258; see also Mayer 2019:103-120). Ancient Christian historians have mixed views about Severian. One of the earliest encomia on Chrysostom's life calls Severian an inarticulate, almost barbarian, pseudo-bishop (Barnes \& Bevan 2013:48, 59). The pro-Chrysostomic writer, Palladius, who wrote a dialogue of Chrysostom's life, is also understandably critical of Severian. For Palladius (Dialogus de vita Joannis Chrysostomi 8; in Malingrey \& Leclerq 1988:170-175), Severian is only worthy of God's judgement. The church historians Socrates and Sozomen saw Severian as an opportunistic and exploitative people-pleaser who wanted to accrue riches through preaching (see Brown 2017:22-23). Gennadius, on the other hand, is much more positive about Severian, calling him 'learned in the Holy Scriptures and a wonderful preacher of homilies' (De viris illustribus supplementum 21; in Richardson 1892:n.p.). Severian needs to be understood on his own terms, and no longer as a type of foil to contextualise Chrysostom; thankfully, there has been progress in Severian studies of late (Voicu 2019:259-283). Although they might have been enemies at the end, their approaches to scripture and preaching are quite similar. This article aims to understand an aspect of Severian's biblical interpretation as such, and hopes to, in some way, assist in rehabilitating and making better known the elusive, and in my opinion, misunderstood and misrepresented bishop of Gabala.

The focus will specifically fall on a homily that has been erroneously attributed to Chrysostom, namely, De paenitentia homilia 7 (CPG 4333). The Greek text of the homily is found in Migne's Patrologiae cursus completus: Series graeca (1862), volume 49 , where it is placed in a series of homilies also known as De paenitentia, which contains authentic material from Chrysostom. Since 1930, however, De paenitentia homilia 7 has been convincingly reattributed to Severian of Gabala in an extensive analysis by Martin (1930:331-343). In 1965, De Aldama listed it in his clavis (no. 395) of PseudoChrysostomic works. The full Latin title reads De paenitentia et compunctione, et quod Deus sit promptus ad salute, tardus ad poenam; et de Rahab historia ['On repentance and remorse, and that God is quick to save and slow to punish; and a history about Rahab'; henceforth referenced as Paen. with the corresponding column and lines in Migne to indicate the specific text], now also listed as CPG 4186. In fact, the exposition on Rahab in this homily, mostly in section $\varepsilon$ of the homily in Migne's text (de Rahab historia; see Migne 1862:49:329-331), adds to the evidence that the homily cannot possibly be an authentic homily of Chrysostom. From the textual tradition, Martin (1930:331-343) points to several different citations and/or summaries from the section de Rahab historia in Procopius of Gaza (the text in col. 329, line 32 to col. 331, line 24 of Migne) and in Nicephorus (four fragments from Migne's col. 330, lines 10-13, 31-33, 35-39 and 55-58) attributed to Severian (cf. Martin 1930:342343). Moreover, Cramer's Catenae Graecorum Patrum (1844:8:18) lists an exposition of James 2:25 (about Rahab) by 
Severian of Gabala that corresponds to Paen. in Migne vol. 49, col. 330, lines 14-18 (see also Martin 1930:332n6). Finally, Paen. 331.14-27 and Severian's In cosmogoniam homilia 2.4 (Migne 1862:56:444) ${ }^{2}$ both exhibit striking similarities in the interpretation of the lie Rahab told to the ruler of Jericho.

There is an English translation of the homily by Christo (1998:86-110); surprisingly, however, Christo (erroneously) assumes the homily to be authentic to Chrysostom. Despite the problems of provenance and authorship in Christo's translation, the translation of the homily itself is not problematic. Stander (2006:37-49) also refers to the account of Rahab in Paen., and also mistakenly attributes the homily to Chrysostom. However, Severian (qua Chrysostom) receives a great deal of attention in Stander's otherwise erudite study. Stander's analysis, however, is more general and focused on the broader Greek patristic tradition, meaning that he has less opportunity to do a close and more detailed reading of the Severian homily about Rahab. What we do notice from reading Stander's study, when the Severian material is highlighted, is that the authentic Chrysostomic materials do not provide such a detailed exposition on Rahab as we find in Severian's homilies. Chrysostom only mentions Rahab in four works considered to be authentic; most of the references are brief. In his first homily In Matthaeum (Migne 1862:57:21), Chrysostom simply acknowledges that the reference to Rahab in the genealogy corresponds to Rahab the harlot. In homily 67 In Matthaeum (Migne 1862:58:638), Chrysostom simply states that despite being a prostitute, Rahab was saved. The majority of other references to Rahab in Chrysostom are simple expositions of the reference to Rahab's faith, mentioned in Hebrews 11:31 (see Chrysostom's second homily In epistulam ad Romanos [Migne 1862:60:409-410]; homilies 26 and 27 In epistulam ad Hebraeos [Migne 1862:63:180, 185-186]; see also the comments of Stander [2006:39-40]). In summary, Chrysostom advises his congregants that they should never be caught having less faith than even a harlot, Rahab, had. Despite the many common homiletical, theological and exegetical similarities often noted between Severian and Chrysostom, ${ }^{3}$ we do not find repetition of any of the detailed themes in Severian's homily - for example, as we will see, Rahab as a type of the church, Rahab as a teacher among the gentiles, Rahab putting Israel to shame, and so on - in the authentic Chrysostomic references to Rahab. Both note the faith of Rahab, but this observation is common in most early Christian references to Rahab. While one should be very cautious in using thematic overlaps in arguments of the authenticity of homilies, in this case, the major thematic differences between Severian's use of Rahab and that of Chrysostom support the codicological evidence. There are also ample additional references to Rahab in other PseudoChrysostomic (but not necessarily Severian) works, some of which will be addressed briefly in this study.

\section{Also known as De mundi creatione (CPG 4194).}

3.For more on the similarities (and differences) between Severian's and Chrysostom's approaches, see several essays in Leemans, Roskam and Segers (2019).
In summary, despite misreadings of authenticity, Stander's study (along with Kritzinger and Botha) remains seminal in that it provides us with a contextualisation of Severian's understanding of Rahab in a broader Greek patristic tradition. However, I am of the opinion that there is much more to be said about Severian's use of the figure of Rahab the harlot. In this brief article, I will provide a close and critical reading of Severian's references to the story of Rahab in Paen. How and why could a treacherous harlot, a prostitute, who was considered to be the epitome of vice in early Christian moral deliberations, function as an exemplum for Severian? I will first ask how Severian deals with the problematic and paradoxical aspects of Rahab, namely, the fact that she was a prostitute and also a liar. Then, I will illustrate how Severian transforms Rahab into a Christian heroine and how he deploys these qualities of the transformed Rahab in a potent anti-Judaistic rhetoric. This discussion will finally conclude with a somewhat broader delineation of the importance of Rahab in the development of a curious Christian cultural and moral trope, namely, the penitent prostitute. Such a study of Rahab is significant not only in that it expands our understanding of the history of women and gender dynamics in early Christianity, but it also elucidates the complex and strategic discursive moves employed by male Christian authors to deal with the seemingly 'bad girls' of scripture. For instance, in Chrysostom's first homily In Matthaeum (Migne 1862:57:21), Rahab is linked with other complex female figures such as Bathsheba, Thamar and Ruth, who were all part of Matthew's genealogy of Jesus. In the PseudoChrysostomic work (not by Severian), In sancta et magna parasceve 2 (Migne 1862:50:814), Rahab is associated with the woman suffering from a flow of blood (Mk 5:25-34) and the Canaanite woman (Mt 15:21-28) from the gospels. With this analysis, essentially, we will witness how a male author, like Severian, 'disciplines' and transforms Rahab into an acceptable female exemplum for his audience, and then uses this exemplum to construct Christian identity in contrast to Jewish identity.

\section{Rahab and the problem of paradox}

How does Severian handle the moral paradox that is the casta meretrix, as Ambrose so eloquently expressed? Severian realises that the figure of Rahab might pose a moral conundrum for his listeners:

Pay attention to me; how strange was the preaching of God's love toward man! He who says in the law, 'You shall not commit

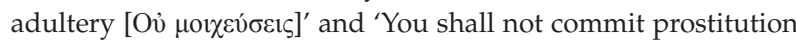

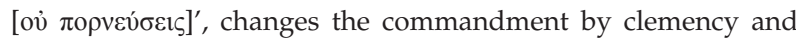
proclaims through the blessed Joshua, 'Let Rahab the prostitute live'. Joshua the son of Nun, who says 'Let the prostitute live', prefigured the Lord Jesus, who says 'The prostitutes and taxcollectors go into the Kingdom of the Heavens before you'. If she must live, how can she be a prostitute? If she is a prostitute, why should she live? (Paen. 329.60-330.5; transl. Christo 1998:98)

Severian and his audience clearly understand the paradox inherent in the story of Rahab. It should be remembered

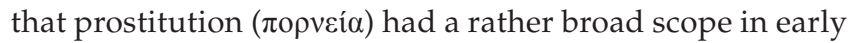




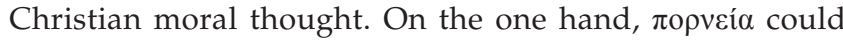
refer, technically, to the profession of harlots; however, for many early Christian authors, as early as the apostle Paul, $\pi$ opveí $\alpha$ came to refer to sexual promiscuity more generally. While non-Christian Roman authors used to make a distinction between adultery ( $\mu$ oเ $\chi \varepsilon i \alpha)$ and prostitution or sexual promiscuity, it is commonly known that most early Christian authors understood all sexual acts associated with $\pi$ opveí $\alpha$ - which included prostitution proper, but also illicit sex acts more generally - as the equivalent of adultery (De Wet 2015:222-232). Roman men, for instance, whether married or not, could engage in sexual acts with prostitutes, slaves (many prostitutes were also slaves) and other non-elite persons, without necessarily being labelled as adulterers or morally reprehensible. In essence, adultery was a crime defined by the status and act of the woman, not the man. Adultery was only a possibility if a freeborn married woman (or perhaps, an elite virgin) was involved in the act itself. In early Christian sexual ethics, this understanding of adultery changed considerably. All sexual acts outside of marriage were reprehensible, and subject to being labelled as adulterous (Kuefler

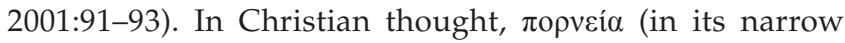
and broad sense) was particularly immoral (Knust 2006:51-54). In the quotation above, we see that Severian

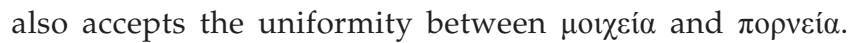
Without a second thought, Severian substitutes the commandment in Exodus 20:14, about adultery, with a commandment more contemporary to his audience: ou

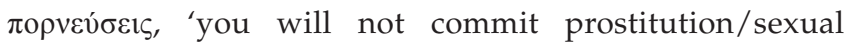
immorality'. Severian therefore reads his own contemporary Christian understanding of adultery and $\pi$ opveí $\alpha$ back into the text of the Old Testament. Adulterers were meant to be executed (stoned), which means prostitutes, in his mind, should also have been executed (although this is not exactly so in the Hebrew Bible, but that is not the point here). So why should Rahab, a prostitute, be allowed to live? Even before he states what is quoted above, Severian says:

Could it be that you sent them [the people of Jericho] an evangelist? Maybe they had someone to point out their interest? He says: 'Yes; I had inside their city to teach them repentance [ $\mu \varepsilon \tau \alpha v o i ́ \alpha c]$ that marvelous Rahab, whom I saved through repentance. She was from the same dough [ $\varphi$ vó́ $\mu \alpha \tau o c]$; however, since she was

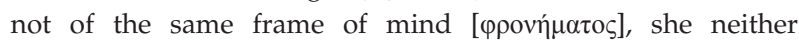
participated in the sin nor resembled the others in faithlessness'. (Paen. 329.55-59; transl. Christo 1998:98)

We now see just how important the figure of Rahab is to Severian; Rahab and the whole story of Jericho's fall are implicitly Christianised by Severian. The purpose of Rahab was to preach repentance, $\mu \varepsilon \tau \alpha v o i ́ \alpha$, to Jericho's people. Why is this important? For Severian, it justifies God's destruction and punishment of Jericho. Before discussing Rahab in detail, Severian contrasts the responses of the cities of Nineveh, which was spared, and Jericho, which was destroyed. Both cities were warned to repent, but Jericho did not. Rahab was to Jericho what Jonah was to Nineveh. She is both a prophetess and a teacher for Severian.
Severian therefore solves the problem of Rahab's paradox by stating that, by the time the spies visited her, she was no longer a prostitute. Prostitution, Severian says, was actually

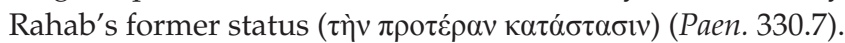
Rahab is not saved because she helped the spies. Theologically, this would not be acceptable for Severian, or for most early Christian authors, in fact. Severian expressly states that Rahab 'reaped the fruits of salvation not only by speech but beforehand by faith and by her disposition before God' (Paen. 330.10-13; trans. Christo 1998:98). By the time the spies arrive, Rahab was already converted and had already preached to the city. She fulfils the requirements of repentance, namely, having come to faith and confessing it. By the time the spies reach Rahab:

[S]he was in a brothel, like a pearl mixed up in mire, like gold thrown in mud, the rose of piety hidden in thorns, a pious soul enclosed in a place of impiety. (Paen. 330.15-18; transl. Christo 1998:98-99; see also Severian's In Chananaeam et Pharaonem 4 [Migne 1862:59:661] for a similar reference)

In this sense, then, Rahab actually becomes a moral example of God's grace to those who repent. Thus, although Rahab was no longer a prostitute, she was still trapped in the brothel. Severian masterfully uses the language of disgust and filth in contrast to that of beauty and piety. As Ambrose called Rahab casta meretrix, the soul of Rahab, for Severian,

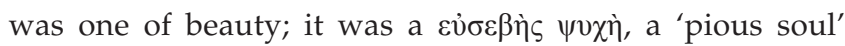
(Paen. 330.18).

Even when Rahab lies to the guards who asked her about the spies, Severian exclaims: 'O this good lie! $\mathrm{O}$ this good fraud, which does not betray the divine, but safeguards the sacred!' (Paen. 331.25-27; trans. Christo 1998:101). Severian was actually quite impressed with Rahab's skill for telling lies. He remarks that Rahab does not lie at the outset. She firstly tells them the truth, that the spies were there, in order to make her story more credible. Then she adds the lie, saying that they fled. As Severian further explains in In cosmogoniam (in Glerup 2010:36, also with reference to $\mathrm{Rahab}^{4}$ ), the best falsehoods have a mixture of truth in order to inspire confidence. But Rahab's lie has the final aim of furthering God's plan, which makes it excusable. In another Pseudo-Chrysostomic work (not by Severian), De circo 1 (Migne 1862:59:570), the author tells his audience to deceive Satan just as Rahab deceived the guards of Jericho (see also Stander 2006:47).

Severian writes (with reference to Heb 11:31, which he thought was written by Paul):

For this reason the noble Paul - who was well appraised of the value of her faith, and did not deem it necessary to reject her for her previous condition, but approved her for her change inspired by God. (Paen. 331.2-6; transl. Christo 1998:100)

Severian further states that the writer of Hebrews 'reckons her with all the saints'. Neither God nor 'Paul' (i.e. the author of Hebrews) rejects Rahab because of her former 4.For more on Severian's homilies on Genesis, see Zellinger (1961). 
condition as a prostitute. Severian is therefore in line with early Christian and Rabbinic thought that reconstructed Rahab as an ideal convert or proselyte. Severian actually ends his de Rahab historia in Paen. by using her as a prime example of the power of repentance, which, we should remember, is the main theme of the homily Paen. Severian restructures the story of Rahab to such an extent that she practically mirrors early Christian practices of $\mu \varepsilon \tau \alpha v o i \alpha$, which required belief and confession.

\section{Rahab in Severian's anti-Judaistic rhetoric}

The fact that Rahab represents the ideal penitent also has ethnic implications in Severian's interpretation of her narrative. As with many other Christian authors, especially with authentic works of Chrysostom, it is not enough for Severian to simply highlight Rahab's faith and repentance. His exegesis soon assumes a polemical tone when he contrasts the faith of Rahab, the harlot, with that of the Israelites. While Rahab acknowledged God while in the filth of Jericho's brothel, Israel, according to Severian, denied God in the desert. In this regard, he refers to Israel's worship of the golden calf. Severian states:

[W] hat Israel heard - he who was surrounded by so many miracles and who was tutored by so many laws - he utterly denied, while Rahab, who was shut in a brothel, teaches them. For she says to the spies: 'We learned about all that your God did to the Egyptians' [Jos 2:9]. The Jew says: 'These are your gods who led you out of the land of Egypt' [Ex 32:4]. And the prostitute, not to the gods but to God Himself, attributes the salvation. (Paen. 330.40-47; transl. Christo 1998:99)

Severian aims for a sense of irony in these unfortunate statements. Essentially, Rahab, although a gentile, acts like the true Israel through her faith in God. Israel, for Severian, is no better than the heathens in its worship of the calf. Severian refers to Exodus 32:4, emphasising that Israel was actually polytheistic:

Wickedness blinds to such a degree, and it fights itself and selfdestructs. They constructed a calf and the ungrateful Israel shouts: 'These are your gods, O Israel, who led you out of the land of Egypt' [Ex 32:4]. These are the gods. He sees one calf. One is the idol that they built. Therefore, why does he say 'These are the gods'? In order to demonstrate that he is worshipping not only that which he sees but the pantheon he imagines. (Paen. 330.32-38; transl. Christo 1998:99)

It is to the shame of Israel that they are 'educated' and even 'disciplined' by a heathen prostitute. The emphasis on Rahab's faith, too, functions polemically in this sense. Following Hebrews 11:31, and also expanding on it, Severian lists Rahab with figures such as Abel, Abraham, Noah and Moses, who all came to faith before the law was given. The same argument with regard to Rahab is made by the anonymous author of the Pseudo-Chrysostomic In sancta et magna parasceve 2 (Migne 1862:50:814). This anti-Judaistic rhetoric then enables Severian to set up Rahab as an image or

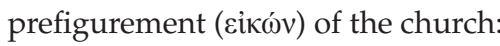

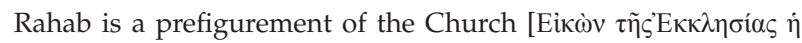
Pà̀ß], which was at one time mixed up in the prostitution of the

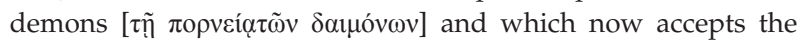
spies of Christ, not the ones sent by Joshua the son of Nun, but the apostles who were sent by Jesus the true Savior. 'I learned', she says, 'that your God is up in heaven and down on the earth, and that apart from Him there is no God' [Jos. 2:11]. The Jews received these things and they did not safeguard them; the Church heard these things and preserved them. Therefore, Rahab, the prefigurement of the Church, is worthy of all praise. (Paen. 330.55-331.2; transl. Christo 1998:100)

Rahab's gentile origins serve as a parallel to the church's gentile origins. Severian describes the former gentile religion of the church as prostitution to demons. But as with Rahab, this was also the church's 'former status'. Of course, Severian does not make much of the fact that Rahab is admitted into Israel. We might assume here that Severian, as is the case with Chrysostom, places Rahab in a category of special Israelites (such as Abraham, Joshua, Paul and even Jesus; see Paen. 331.6-10), who set themselves against the views of the majority (for more on this issue, see Jacobs 2006:258-286).

Severian's interpretation of the Rahab narrative shows how disturbingly discourses of gender, culture and ethnicity often overlap in early Christian polemics against Jews (see also Drake 2013:1-18). In his interpretation, Severian himself disciplines and Christianises the 'bad girl', that is, Rahab, and transforms her into a 'good girl'. However, in doing so, he also utilises this new bad-girl-turned-good to create new categories of 'bad girls' and harlots, namely, the Jews. Severian claims what we might call the cultural capital of the Jews, namely, Rahab from the Hebrew Bible/Septuagint, and displays her to his audience as a penitent 'Christian before Christ', so to speak. Although Severian does not say it explicitly here, the assumption of his rhetoric is that the Jews are now the 'harlots' in terms of their spiritual and moral practice. Severian's invective here is a form of antiJudaistic sexual slander. Chrysostom was explicit in calling Jews prostitutes and the synagogue a brothel, as Drake (2013:78-98) has demonstrated. Like Chrysostom, Severian too had a potent repertoire regarding anti-Judaism as is seen, for instance, in his homilies Contra Iudaeos et Graecos et haereticos (CPG 4233 \& 5027) and Contra Iudaeos in serpentem aeneum (CPG 4207) (on Severian's anti-Judaistic tendencies, see especially Kecskeméti 2005:131-178). The aim of the rhetoric is to present Christianity as pious and chaste (and masculine) and Judaism as idolatrous and concupiscent (and effeminate).

\section{Conclusion: Rahab and the rise of the penitent prostitute in early Christianity}

In conclusion, we have seen in this study that Severian transforms Rahab into a penitent prostitute who becomes a teacher and even a prophet for the gentiles. As an image of 
the church, Rahab is set in direct opposition to Jewish identity. Yet, what we often fail to realise is that this ethnosexual rhetoric used to construct Christian identity (in opposition to Jewish identity) often resulted in some interesting culturally discursive 'debris'. One of these is the rise and popularisation of the figure of the penitent prostitute in early Christianity, for whom Rahab might have been a perfect scriptural exemplum.

Some of the most famous stories of penitent prostitutes include The Life of Thais (in the tradition of the Sayings of the Desert Fathers), the Life of Pelagia and the later Life of Mary of Egypt. Regarding the figure of the penitent prostitute, Harper (2013) remarks:

The stories of the penitent prostitutes, as a subgenre, mirror the coming of age of Christianity as a dominant public ideology. The woman's body was a potent symbol, a shorthand for the order of society. At the deepest level, the redemption of a prostitute's corrupted flesh stood for the ability of the church to absorb society and through baptism to cleanse it. The prostitute's sins are only an exaggerated and especially condensed symbol of the sins of the world. The prostitute is everyman. (pp. 234-235)

This observation leads us to consider a scriptural and exegetical figure like Rahab, who appears marginal at first, with more earnestness. After all, a figure as prominent as the penitent prostitute required a scriptural and exegetical mandate and basis. Did Severian have the figure of the penitent prostitute in mind when speaking about Rahab? One can only speculate about this. It is at least possible that he knew about the legend of one such figure, namely, Pelagia, a former prostitute and actress of Antioch, who became an ascetic. With regard to Pelagia's name, we read the following in the Life of Pelagia (trans. Waddell 1957 [slightly adapted]):

Then said the good bishop Nonnus, 'Tell me your name'. She answered, 'My own name was Pelagia, that my father and mother gave me: but the townsfolk of Antioch call me Margarita, because of the pearls with which they jewelled my sins. For I was the devil's jewel and his armoury'. (pp. 183-184)

Pelagia's professional name was Margarita, which means 'pearl' in Greek (i.e. $\mu \alpha \rho \gamma \alpha \rho i$ ins). Severian refers to Rahab

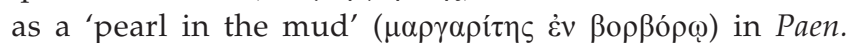
330.16 and in In Chananaeam et Pharaonem 4 (Migne 1862:59:661). Did Severian perhaps have Pelagia in mind when he wrote about Rahab? Of course, we simply cannot know. There is one early reference to Pelagia outside of the Life of Pelagia that is significant. Chrysostom himself refers, somewhat cryptically, to Pelagia in his homily 67 In Matthaeum. In this homily, Chrysostom links the figure of Rahab and Pelagia.

We do not need an explicit link between Rahab and the penitent prostitutes of early Christianity, however, to see the relevance of their impact in the making of early Christian culture and identity. It seems that the findings of Raveh for Rahab in Rabbinic literature concur with what we have seen here in Severian. Raveh (2014:113) refers to a homology between gender identity and group identity, in which gender is used to speak about the ethnic other. What we see from this analysis of Severian's de Rahab historia is that penitent prostitutes from the Bible, of which Rahab is not the only one, and those in the days of Severian himself, were potent symbols of Christian ethno-sexual power and identity discourses. When Severian calls Rahab an image of the church, he calls each Christian to identify with Rahab in some way or another. As Rahab taught about God in the brothel of Jericho, so too does she still function as a pedagogical example for the church. Rahab moves from the margins of scripture to the very centre of theology. By transforming Rahab the harlot into Rahab the penitent, Severian re-imagines the salvation history of the Old Testament in strategically gendered Christian terms.

\section{Acknowledgements}

The author thanks Katherin Papadopoulos (Australian Lutheran College, Adelaide) for her valuable comments related to this study.

\section{Competing interests}

The author has declared that no competing interests exist.

\section{Author's contributions}

I declare that I am the sole author of this research article.

\section{Ethical consideration}

This article followed all ethical standards for a research without direct contact with human or animal subjects.

\section{Funding information}

This research received no specific grant from any funding agency in the public, commercial or not-for-profit sectors.

\section{Data availability statement}

Data sharing is not applicable to this article as no new data were created or analysed in this study.

\section{Disclaimer}

The views and opinions expressed in this article are the author's own and do not necessarily reflect the official policy or position of any affiliated agency of the author.

\section{References}

Barnes, T.D. \& Bevan, G. (eds. \& trans.), 2013, The funerary speech for John Chrysostom, Translated Texts for Historians 60, Liverpool University Press, Liverpool.

Baskin, J., 1979, 'The rabbinic transformations of Rahab the Harlot', Notre Dame English Journal 11(2), 141-157.

Bauckham, R., 1995, 'Tamar's ancestry and Rahab's marriage: Two problems in the Matthean Genealogy', Novum Testamentum 37(4), 313-329. https://doi. org/10.1163/1568536952663168 
Botha, P.J., 2006, 'Tamar, Rahab, Ruth, and Mary-The bold women in Ephrem the Syrian's Hymn De Nativitate 9', Acta Patristica et Byzantina 17(1), 1-21. https:// Syrian's Hymn De Nativitate 9', Acta Patristica
doi.org/10.1080/10226486.2006.11745765

Brown, D., 2017, 'The Christology of Severian of Gabala: In what sense can he be called Antiochene', Unpublished PhD dissertation, Evangelische Theologische Faculteit, Leuven.

Christo, G.G. (trans.), 1998, St. John Chrysostom: On repentance and almsgiving, The Fathers of the Church 96, Catholic University of America Press, Washington, DC.

Cramer, J.A. (ed.), 1844, Catenae Graecorum Patrum in Novum Testamentum, vol. 8, E Typographeo Academico, Oxford.

De Aldama, J.A., 1965, Repertorium Pseudochrysostomicum, Documents, études et répertoirespubliés par l'Institut de recherche et d'histoire des textes 10, Éditions du Centre national de la recherche scientifique, Paris.

De Wet, C.L., 2015, Preaching bondage: John Chrysostom and the discourse of slavery in early Christianity, University of California Press, Oakland, CA.

Drake, S., 2013, Slandering the Jew: Sexuality and difference in early Christian texts, Divinations: Rereading Late Ancient Religion, University of Pennsylvania Press, Philadelphia, PA.

Glerup, M. (ed.), Hill, R.C. \& Hardin, C.S. (trans.), 2010, Commentaries on Genesis 1-3: Severian of Gabala and Bede the Venerable, Ancient Christian Texts, IVP Academic, Downers Grove, IL.

Hanson, A.T., 1978, 'Rahab the Harlot in Early Christian tradition', Journal for the Study of the New Testament 1, 53-60. https://doi.org/10.1177/0142064X7800100106

Harper, K., 2013, From shame to sin: The Christian transformation of sexual morality in late antiquity, Harvard University Press, Cambridge, MA.

Jacobs, A.S., 2006, 'A Jew's Jew: Paul and the early Christian problem of Jewish origins', Journal of Religion 86(2), 258-286. https://doi.org/10.1086/499635

Japinga, L., 2017, Preaching the women of the old testament: Who they were and why they matter, Westminster John Knox Press, Louisville, KY.

Kecskeméti, J., 2005, Une rhétorique au service de l'antijudaïsme: IVe siècle'VIle siècle, Bibliothèque d'études juives 26, $\mathrm{H}$. Champion, Paris.

Knust, J.W., 2006, Abandoned to lust: Sexual slander and ancient Christianity, Columbia University Press, New York, NY.

Kritzinger, J.P.K., 2006, 'Rahab, Illa Meretrix', Acta Patristica et Byzantina 17(1), 22-36. https://doi.org/10.1080/10226486.2006.11745766

Kuefler, M., 2001, The Manly Eunuch: Masculinity, gender ambiguity, and Christian ideology in late antiquity, The Chicago Series on Sexuality, History, and Society, University of Chicago Press, Chicago, IL.
Leemans, J., Roskam, G. \& Segers, J. (eds.), 2019, John Chrysostom and Severian of Gabala: Homilists, exegetes and theologians, Orientalia Lovaniensia Analecta 282, Peeters, Leuven.

Lyons, W.L., 2008, 'Rahab through the ages: A study of Christian interpretation of Rahab', SBL Forum, viewed 14 August 2020, from http://sbl-site.org/Article. aspx?ArticlelD $=786$

Malingrey, A.M. \& Leclerq, P. (eds. \& trans.), 1988, Dialogue sur la vie de Jean Chrysostome, vol. 1, Sources Chretiennes 341, Cerf, Paris.

Martin, C., 1930, 'Une homélie De Poenitentia de Sévérien de Gabala', Revue d’histoire ecclésiastique 26(2), 331-343.

Mayer, W.E., 2019, 'Severian and John on authority: Exploring the agency of their preaching in the Johannite Schism', in J. Leemans, G. Roskam \& J. Segers (eds.), John Chrysostom and Severian of Gabala: Homilists, exegetes and theologians, Orientalia Lovaniensia Analecta 282, pp. 103-120, Peeters, Leuven.

Migne, J.-P. (ed.), 1862, Patrologiae cursus completus: Series graeca, 162 vols., Migne, Paris.

Quin, J.D., 1981, 'Is PAXAB in Mt 1.5 Rahab of Jericho?' Biblica 62(2), 225-228.

Raveh, I., 2014, Feminist rereadings of Rabbinic literature, Brandeis University Press, Waltham, MA.

Richardson, E.C., 1892, 'Gennadius: Supplement to De viris illustribus', in P. Schaff \& H. Wace (eds.), Nicene and post-nicene fathers, Second Series, vol. 3, Christian Literature Publishing Co., Buffalo, NY, viewed 13 August 2020, from http://www. newadvent.org/fathers/2719.htm.

Stander, H.F., 2006, 'The Greek Church Fathers and Rahab', Acta Patristica et Byzantina 17(1), 37-49. https://doi.org/10.1080/10226486.2006.11745767

Van Nuffelen, P., 2019, 'Boundless ambition or a friendship that went wrong? Narrating the conflict between John Chrysostom and Severian of Gabala', in J. Leemans, G. Roskam \& J. Segers (eds.), John Chrysostom and Severian of Gabala: Leemans, G. Roskam \& J. Segers (eds.), John Chrysostom and Severian of Gabala:
Homilists, exegetes and theologians, Orientalia Lovaniensia Analecta 282, Homilists, exegetes and the
pp. 245-258, Peeters, Leuven.

Voicu, S.J., 2014, 'Severian of Gabala', in A. Di Berardino (ed.), Encyclopedia of ancient Christianity: Volume 3, pp. 563-564, IVP Academic, Downers Grove, IL.

Voicu, S.J., 2019, 'A century of progress on the homilies of Severian of Gabala,' in J. Leemans, G. Roskam \& J. Segers (eds.), John Chrysostom and Severian of Gabala: Homilists, exegetes and theologians, Orientalia Lovaniensia Analecta 282, pp. 259-283, Peeters, Leuven.

Zellinger, J., 1916, Die Genesishomilien des Bischofts Severian von Gabala, Aschendorff, Münster. 